\title{
Hypoglycaemic effects of Parkia biglobosa (Jacq) Benth seed extract in glucose-loaded and NIDDM rats
}

\author{
A. A. FRED-JAIYESIMI ${ }^{1 *}$ and K. A. ABO ${ }^{2}$ \\ ${ }^{1}$ Department of Pharmacognosy, Olabisi Onabanjo university, Sagamu. Ogun State, Nigeria. \\ ${ }^{2}$ Department of Pharmacognosy, University of Ibadan. Oyo State. Nigeria. \\ *Corresponding author, Email: adediwurajaiyesimi@gmail.com, Tel: +2348022898155.
}

\begin{abstract}
The antidiabetic potentials of the methanol extract of Parkia biglobosa seed (Mimosoideae), its chloroform, hexane, and mother liquor fractions were evaluated in glucose-loaded and alloxan-induced diabetic rats. The methanol extract of the seed exhibited a peak percentage decrease of $64 \%$ and $44.1 \%$ in blood glucose levels of the glucose-loaded and alloxan-induced diabetic rats respectively. The blood glucose lowering effect of the chloroform fraction $(65.7 \% ; \mathrm{p}<0.05)$ was significant and more than that exhibited by the reference drug glibenclamide in the alloxan-induced diabetic rats.
\end{abstract}

(C) 2009 International Formulae Group. All rights reserved.

Keywords: Alloxan-induced, antidiabetic, glucose-loaded Parkia biglobosa.

\section{INTRODUCTION}

Parkia biglobosa (Jacq) Benth

(Mimosoideae), commonly known as 'African

Locust beans', is widely distributed across the Sudan and Guinea savannah ecological zones ranging from Senegal across to Sudan (Hopkins, 1983). Parkia species have found use traditionally as foods and medicinal agents. P. biglobosa fermented seeds are used in all parts of Nigeria and West Africa for seasoning traditional soups (Ajaiyeoba, 2002).

In folklore medicine, $P$. biglobosa is used by traditional healers in Southwest Nigeria and Senegal for the treatment of Diabetes mellitus (Abo et al., 2008; Die'yea et al., 2008) and in Northern Nigeria, it is used in the treatment of diarrheal infections (Abdulkarim et al., 2005).

Previous biological studies of $P$. biglobosa have reported the antimicrobial activities of the leaf and stem bark (Ajaiyeoba, 2002; Millogo-Kone et al., 2006; 2007; 2008). The aqueous and acetone extract of $P$. biglobosa raw beans have also demonstrated termicidal properties (Femi-Ola et al., 2008). Other studies have also reported the possible antidiabetic potentials of the methanol extract of the seeds of $P$. biglobosa in alloxan-induced diabetic rats (Odetola et al., 2006), the hypotensive and/or hypoglycemic effect in guinea pig, rat and rabbit (Kodjo et al., 2006).

With this in mind, this study aimed at investigating the blood glucose lowering effect of the methanol crude extract, nhexane, chloroform and mother liquor fractions of $P$. biglobosa fermented seeds in oral glucose-loaded and non-insulin dependent diabetic (NIDDM) rats.

\section{MATERIALS AND METHODS \\ Plant material}

Parkia biglobosa fermented seeds were purchased from Bodija market, Ibadan, Oyo State, Nigeria. The plant was authenticated at the Department of Pharmacognosy, Olabisi 
Onabanjo University Sagamu with a voucher number FJ051. The plant material was dried and ground into powder.

\section{Phytochemical screening of $P$. biglobosa seed}

Phytochemical screening was carried out using methods adopted from Trease and Evans, 1996.

\section{Preparation of methanol extract}

$100 \mathrm{~g}$ dried powdered seed of $P$. biglobosa was macerated in $80 \%$ methanol for four days. The extract was filtered and filtrate dried in vacuo. The residue $(5.6 \mathrm{~g})$ was stored in dessicator and used for subsequent assays.

\section{Preparation of n-hexane and chloroform fractions of Parkia biglobosa fermented seed}

Dried crude methanol extract of $P$. biglobosa fermented seed was suspended in $\mathrm{MeOH}-\mathrm{H}_{2} \mathrm{O}$ (1:9) and partitioned with nhexane and chloroform successively to yield the $\mathrm{n}$-hexane, chloroform fractions and mother liquor.

\section{Animals}

Healthy wistar albino rats weighing between $80-250 \mathrm{~g}$ were used for the study. The animals were housed in polypropylene cages, maintained under standard conditions. They were fed with standard rat pellet diet (Ladokun feeds, Ibadan) and water ad libitum.

\section{Antidiabetic studies \\ Oral glucose load test}

Twenty healthy albino rats fasted overnight $(18 \mathrm{~h})$. Group $1(\mathrm{n}=5)$, group 2 $(n=5)$ and group $3(n=5)$ rats were fed $2 \mathrm{~g}$ glucose/kg body weight orally (dissolved in water) through a canulla, with a fourth group of rats $(n=5)$ administered water. Immediately after glucose loading, group 1 and 2 rats $(\mathrm{n}=$ 5) were administered methanol extract (1 $\mathrm{g} / \mathrm{kg}$ ) and glibenclamide $(5 \mathrm{mg} / \mathrm{kg})$ respecttively, while group 3 rats were administered water only. Blood was withdrawn from the tail of the animals at $0,1,2,3,4,5,6$ and 7 hrs. The fasting blood glucose levels were estimated by the O-toluidine methods (Dubowski, 1962; Frings, Ratliff and Dunn, 1970).

\section{Induction of non-insulin dependent diabetes mellitus}

NIDDM was induced in thirty- five rats by a single intraperitoneal injection of 60 $\mathrm{mg} / \mathrm{kg}$ Alloxan monohydrate (Abdel-Barry et al., 1997) (Sigma Aldrich, UK). Hyperglycaemia was confirmed by the elevated glucose level in the blood, determined at $72 \mathrm{hrs}$ after injection.

\section{Experimental design}

The diabetic animals were divided into seven groups. Following overnight fast, group 1 diabetic rats $(\mathrm{n}=5)$ received methanol extract of $P$. biglobosa $(1 \mathrm{~g} / \mathrm{kg})$ reconstituted in water, group 2 diabetic rats $(\mathrm{n}=5)$ received $\mathrm{n}$ hexane fraction of $P$. biglobosa $(1 \mathrm{~g} / \mathrm{kg})$ as a suspension, group 3 diabetic rats $(\mathrm{n}=5)$ received chloroform fraction of $P$. biglobosa $(1 \mathrm{~g} / \mathrm{kg})$ as a suspension, group 4 diabetic rats $(\mathrm{n}=5)$ received mother liquor fraction of $P$. biglobosa $(1 \mathrm{~g} / \mathrm{kg})$ reconstituted in water, group 5 diabetic rats $(n=5)$ were treated with oral hypoglycaemic agent glibenclamide (5 $\mathrm{mg} / \mathrm{kg}$ ), group 6 diabetic rats ( $\mathrm{n}=5$; untreated) received water only $(2 \mathrm{ml} / \mathrm{kg})$ and group 7 $(\mathrm{n}=5)$ normal (non-diabetic) rats received water only $(2 \mathrm{ml} / \mathrm{kg})$. The fasting blood glucose was determined by nipping of the tail tip and measuring the blood glucose with a one touch life scan glucometer (Lifescan, Johnson and Johnson Inc., California) at 0, 2 , 4,6 , and 8 hours after extract administration using the glucose-oxidase method.

\section{Statistical analysis}

Data are expressed as mean \pm SEM. The significance of the differences between the means of the test and control animals was established by the student $\mathrm{t}$-test.

\section{Activity of the plant in glucose-loaded rats}

The administration of $P$. biglobosa methanol extract exhibited a pronounced effect on blood glucose in the glucose-loaded rats at 5 and 6 hrs. A peak hypoglycaemic effect of $34.3 \%(p<0.05)$ was observed in the group administered the methanol extract when compared to the untreated glucose-loaded rats and $64 \%$ decrease in blood glucose level when compared to $1 \mathrm{hr}$. The hypoglycaemic effect of the methanol extract at a dose of $1 \mathrm{~g} / \mathrm{kg}$ was lower than that of the reference drug glibenclamide throughout the study (Table 2). 
A. A. FRED-JAIYESIMI and K. A. ABO / Int. J. Biol. Chem. Sci. 3(3): 545-550, 2009

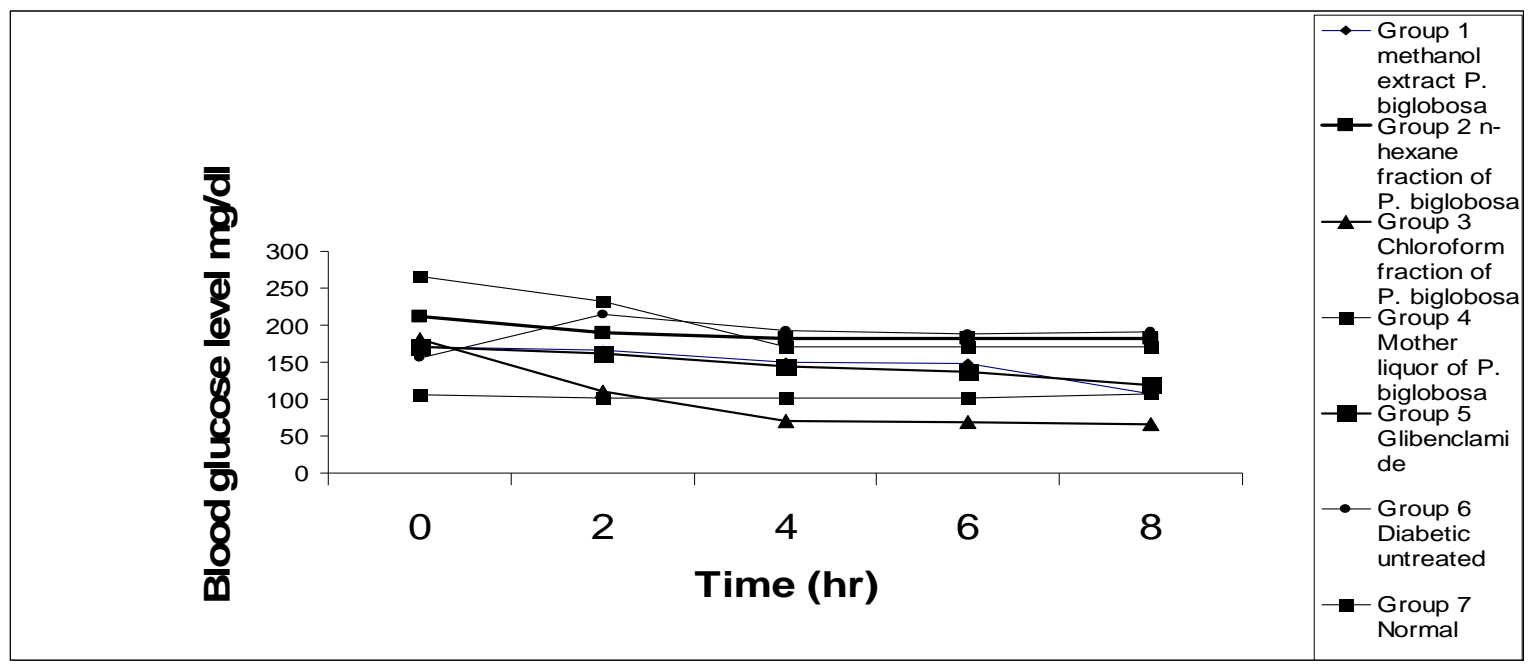

Figure 1: Effect of Parkia biglobosa methanol seed extract and fractions on alloxan-induced diabetic rats.

Table 1: Summary of phytochemical screening of Parkia biglobosa fermented seed.

\begin{tabular}{|c|c|c|c|c|c|c|c|c|}
\hline Anth & quinones & Tannins & Alkaloids & $\begin{array}{c}\text { Cyanogenetic } \\
\text { glycosides }\end{array}$ & Sterols & Saponins & $\begin{array}{c}\text { Cardiac } \\
\text { glycosides }\end{array}$ & Flavonoids \\
\hline Free & Combined & & & & & & & \\
\hline- & - & ++ & + & - & + & ++ & - & - \\
\hline
\end{tabular}


A. A. FRED-JAIYESIMI and K. A. ABO / Int. J. Biol. Chem. Sci. 3(3): 545-550, 2009

Table 2: Effect of methanol seed extract of Parkia biglobosa on oral glucose-loaded test.

\begin{tabular}{|c|c|c|c|c|c|c|c|c|}
\hline \multirow{2}{*}{ Treatment } & \multicolumn{8}{|c|}{ Time (hour) and mean blood glucose level (mg/dl) } \\
\hline & 0 & 1 & 2 & 3 & 4 & 5 & 6 & 7 \\
\hline $\begin{array}{l}\text { Group 1: P. biglobosa } \\
\text { methanol see extract }(1 \mathrm{~g} / \mathrm{kg})\end{array}$ & $100.0 \pm 1.255$ & $263.0 \pm 1.061$ & $\begin{array}{l}230.4 \pm 0.849 \\
\quad(12.4 \%)\end{array}$ & $\begin{array}{c}167.4 \pm 0.990 \\
(36.3 \%)\end{array}$ & $\begin{array}{l}147.8 \pm 0.707 \\
(43.8 \%)\end{array}$ & $\begin{array}{l}94.6 \pm 0.106^{*} \\
(64.0 \%)\end{array}$ & $\begin{array}{l}104.0 \pm 0.990 * \\
(60.5 \%)\end{array}$ & $\begin{array}{l}106.4 \pm 1.145 \\
(59.5 \%)\end{array}$ \\
\hline $\begin{array}{l}\text { Group 2: } \\
\text { Glibenclamide (5 } \\
\mathrm{mg} / \mathrm{kg} \text { ). }\end{array}$ & $81.4 \pm 0.127$ & $178.1 \pm 0.566$ & $\begin{array}{l}154.0 \pm 0.025 \\
\quad(13.5 \%)\end{array}$ & $\begin{array}{l}131.8 \pm 0.355 * \\
\quad(25.9 \%)\end{array}$ & $\begin{array}{l}109.5 \pm 1.598 * \\
\quad(38.5 \%)\end{array}$ & $\begin{array}{l}80.4 \pm 1.075^{*} \\
\quad(54.9 \%)\end{array}$ & $\begin{array}{l}76.4 \pm 0.292 * \\
\quad(57.1 \%)\end{array}$ & $\begin{array}{l}71.9 \pm 0.150 * \\
\quad(59.6 \%)\end{array}$ \\
\hline $\begin{array}{l}\text { Group 3: Control } \\
\text { Diabetic untreated }\end{array}$ & $91.3 \pm 1.363$ & $156.3 \pm 0.445$ & $154.0 \pm 0.294$ & $159.7 \pm 0.321$ & $152.9 \pm 0.963$ & $144.0 \pm 0.113$ & $136.1 \pm 0.740$ & $125.8 \pm 0.005$ \\
\hline Group 4: Normal & $100.0 \pm 0.141$ & $98.2 \pm 0.141$ & $99.0 \pm 0.035$ & $99.1 \pm 0.033$ & $98.1 \pm 0.035$ & $89.5 \pm 0.707$ & $90.5 \pm 0.532$ & $89.9 \pm 0.371$ \\
\hline
\end{tabular}

Values are expressed as Mean \pm SEM; $\mathrm{P}<0.05 ; \mathrm{n}=5$; Figures in parenthesis $=\%$ decrease in blood glucose level (compared to blood glucose level at $1 \mathrm{hr}$ ); * Represents statistical

significance vs. control (untreated diabetic group) $\mathrm{P}<0.05$.

Table 3: Effect of Parkia biglobosa seed methanol extract, n-hexane, chloroform, mother liquor fractions on alloxan-induced diabetic rats

\begin{tabular}{|c|c|c|c|c|c|}
\hline \multirow{2}{*}{ Treatment } & \multicolumn{5}{|c|}{ Time (hour) and mean blood glucose level (mg/dl) } \\
\hline & (0) & 2 & 4 & 6 & 8 \\
\hline Group 1 : Methanol extract of $P$. biglobosa seed. $(1 \mathrm{~g} / \mathrm{kg})$ & $170.4 \pm 1.200$ & $\begin{array}{c}166.7 \pm 0.313 \\
(22.4 \%)^{*}\end{array}$ & $\begin{array}{c}150.0 \pm 1.249 \\
(22.1 \%)^{*}\end{array}$ & $\begin{array}{c}148.1 \pm 0.946 \\
(21.6 \%)^{*}\end{array}$ & $\begin{array}{c}106.7 \pm 1.569 \\
(44.1 \%)^{*}\end{array}$ \\
\hline Group 2: n-hexane fraction of $P$. biglobosa seed & $212.2 \pm 1.204$ & $\begin{array}{c}190.4 \pm 0.811 \\
(11.4 \%)\end{array}$ & $\begin{array}{c}181.7 \pm 1.569 \\
(5.7 \%)\end{array}$ & $\begin{array}{c}181.7 \pm 1.589 \\
(3.8 \%)\end{array}$ & $\begin{array}{c}181.7 \pm 1.194 \\
(4.7 \%)\end{array}$ \\
\hline Group 3 : Chloroform fraction of $P$. biglobosa seed & $180.2 \pm 1.146$ & $\begin{array}{c}110.4 \pm 1.185 \\
(52.6 \%)^{*}\end{array}$ & $\begin{array}{c}70.2 \pm 1.2010 \\
(63.6 \%)^{*}\end{array}$ & $\begin{array}{c}69.8 \pm 1.511 \\
(63.1 \%)^{*} \\
\end{array}$ & $\begin{array}{c}65.5 \pm 1.284 \\
(65.7 \%)^{*} \\
\end{array}$ \\
\hline Group 4 : Mother liquor of $P$. biglobosa seed & $246.7 \pm 1.205$ & $231.9 \pm 1.378$ & $\begin{array}{c}170.3 \pm 1.401 \\
11.6 \% \\
\end{array}$ & $\begin{array}{c}170.3 \pm 1.255 \\
(9.9 \%) \\
\end{array}$ & $\begin{array}{c}170.2 \pm 1.387 \\
(10.8 \%)\end{array}$ \\
\hline Group 5 : Glibenclamide (5 mg/kg) & $171.1 \pm 0.992$ & $\begin{array}{c}162.3 \pm 1.215 \\
(24.4 \%)^{*}\end{array}$ & $\begin{array}{c}144.4 \pm 1.576 \\
(25.0 \%)^{*}\end{array}$ & $\begin{array}{c}137.0 \pm 0.992 \\
(27.5 \%)^{*}\end{array}$ & $\begin{array}{c}118.5 \pm 3.139 \\
(37.9 \%)^{*}\end{array}$ \\
\hline Group 6: Untreated diabetic & $155.6 \pm 0.035$ & $214.8 \pm 1.005$ & $192.6 \pm 0.990$ & $188.9 \pm 1.112$ & $190.7 \pm 2.970$ \\
\hline Group 7: Normal (non-diabetic) & $105.5 \pm 3.337$ & $101.8 \pm 2.903$ & $101.1 \pm 0.044$ & $101.1 \pm 0.047$ & $106.7 \pm 1.213$ \\
\hline
\end{tabular}


Activity of the plant in alloxan-induced diabetic rats

In the alloxan diabetic rats, the result of the hypoglycaemic effect of the methanol extract, chloroform, hexane fractions and mother liquor of $P$. biglobosa showed that the chloroform fraction exhibited the most pronounced hypoglycaemic effect $(\mathrm{p}<0.05)$. The chloroform fraction maintained a stable hypoglycaemic effect in the alloxan-induced diabetic rats and a peak decrease in blood glucose level of $65.7 \%$ at $8 \mathrm{hr}$ was observed. The hypoglycaemic activity of the chloroform fraction at a dose of $1 \mathrm{~g} / \mathrm{kg}$ was markedly higher than that of the reference drug Glibenclamide $(5 \mathrm{mg} / \mathrm{kg})$ in the alloxaninduced diabetic rats. A dose of $1 \mathrm{~g} / \mathrm{kg}$ of the methanol extract exhibited a similar hypoglycaemic effect as the reference drug at a dose of $5 \mathrm{mg} / \mathrm{kg}$ in the alloxan-induced diabetic rats.

\section{RESULTS}

\section{Phytochemical}

The phytochemical screening of $P$. biglobosa fermented seed revealed the presence of alkaloids, saponins, steroids and tannins (Table 1).

\section{DISCUSSION}

The phytochemical screening in this study revealed the presence of alkaloids, saponins, steroids and tannins in the fermented seed. This is in agreement with previous reports of the presence of alkaloids, tannins, cardiac glycoside and steroids in the leaf (Ajaiyeoba, 2002) and presence of sterols/triterpenes, coumarins, flavones, anthraquinones, tannins, anthocyanins and saponins in the stem bark (Millogo - Kone et al., 2006). However, in this study, Cardiac glycosides and anthraquinones were not present in the fermented seeds.

$P$. biglobosa methanol extract administered to the glucose-loaded diabetic rats exhibited a decrease in the blood glucose levels of the animals throughout the period of the study, with a peak decrease in blood glucose level of $64 \%$ at $5 \mathrm{hr}$. The hypoglycaemic effect of $P$. biglobosa methanol extract is similar to that of glibenclamide. There was no significant difference in the activity of the methanol extract and glibenclamide at $5 \mathrm{hr}, 6 \mathrm{hr}$ and 7 hr (Table 2).

In this study, the methanol extract administered to the alloxan-induced diabetic rats decreased the blood glucose level by $44.1 \%$ at $8 \mathrm{hr}$ while in previous study on the possible antidiabetic potentials of $P$. biglobosa, a dose of $6 \mathrm{~g} / \mathrm{kg}$ of the methanol extract administered to alloxan-induced diabetic rats as a dietary supplement for a period of four weeks, exhibited a decrease in blood glucose level of $64.4 \%$ (Odetola et al., 2006). The activity of the methanol extract is similar to that of glibenclamide. This study is in agreement with previous studies and confirms the blood glucose lowering effect of methanol extract of $P$. biglobosa fermented seed.

However, the chloroform fraction exhibited the most pronounced activity with a peak decrease in blood glucose level of $65.7 \%$ at $8 \mathrm{hr}$. The hypoglycaemic activity of the chloroform fraction at a dose of $1 \mathrm{~g} / \mathrm{kg}$ was markedly higher than that of the reference drug glibenclamide $(5 \mathrm{mg} / \mathrm{kg})$ in the alloxaninduced diabetic rats (Table 3 ).

The exact mechanism of action and group of secondary metabolite(s) responsible for the antidiabetic activity of $P$. biglobosa fermented seed is unknown. Further study is on-going to identify the active compound(s) responsible for the antidiabetic and hypoglycaemic activities in the methanol extract and its chloroform fraction.

\section{REFERENCES}

Abdel-Barry JA, Abdel-Hassan IA, Mohammad H, Al- Hakiem H. 1997. Hypoglycaemic and antihyperglycaemic effects of Trigonella foenum-graecum leaf in normal and alloxan-induced diabetic rats. Journal of Ethnopharmacology, 58(3): 149-155.

Abdulkarim A, Sadiq Y, Gabriel OA, Abdulkadir U Zi, Abdurahman EM. 2005. Evaluation of five medicinal plants used in diarrhoea treatment in Nigeria. Journal of Ethnopharmacology, 101(1-3): 27-30.

Abo KA, Fred-Jaiyesimi AA, Jaiyesimi AEA. 2008. Ethnobotanical studies of medicinal plants used in the management of Diabetes mellitus in South Western 
Nigeria. Journal of Ethnopharmacology, 115(1): 67 -71.

Ajaiyeoba EO. 2002. Phytochemical and antibacterial properties of Parkia biglobosa and Parkia bicolour leaf extracts. African Journal of Biomedical research, 5: 125-129.

Asuzu IU, Harvey AL. 2003. The antisnake venom activities of Parkia biglobosa (Mimosaceae) stem bark extract. Toxicon, 42(7): 763-768.

Die'yea AM, Sarrb A, Diopb SN, Ndiayea M, Sya GY, Diarrac M, Gaffarya I, Sya A, Fayea B. 2008. Medicinal plants and the treatment of diabetes in Senegal: survey with patients. Fundam Clin. Pharmacol., 22(2): $211-216$.

Dubowski KM. 1962. An O-toluidine method for body-fluid glucose determination. Clinical Chemistry, 8: 215-235.

Femi-Ola TO, Ajibade VA, Afolabi A. 2008. Chemical composition and Termicidal properties of Parkia biglobosa (Jacq) Benth. Journal of Biological Sciences, 8(2): $494-497$.

Frings CS, Ratliff CR, Dunn RT. 1970. Automated determination of glucose in serum or plasma by a direct O-toluidine procedure. Clinical Chemistry, 16: 282.

Hopkins HC. 1983. The taxonomy, reproductive biology and economic potential of Parkia (Leguminosae: Mimosoideae) in Africa and Madagascar. Botanical Journal of the Linnean Society, 87: 135137.
Kodjo KM, Contesse JL, Do Rego, Aklikokou $\mathrm{K}$, Titrikou S, Gbeassor M, Vaudry $\mathrm{H}$. 2006. The Journal of Steroid Biochemistry and Molecular Biology, 100(4 - 5): 202 - 208.

Millogo - Kone H, Guissou JP, Nacoulma O, Traore AS. 2006. Study of the antibacterial activity of stem bark and leaf extracts of Parkia biglobosa (Jacq) Benth on Staphylococcus aureus. African Journal of Complimentary and Alternative Medicine, 3(2): 74 - 78.

Millogo - Kone H, Guissou JP, Nacoulma O, Traore AS. 2007. Antimicrobial effects of the stem bark extracts of Parkia biglobosa on Shigellae. African Journal of Complimentary and Alternative Medicine, 4(4): 392 - 396.

Millogo - Kone H, Guissou JP, Nacoulma O, Traore AS. 2008. Comparative study of leaf and stem bark extracts of Parkia biglobosa against enterobacteria. African Journal of Complimentary and Alternative Medicine, 5(3): 238 - 243.

Odetola AA, Akinloye O, Egunjobi C, Adekunle WA, Ayoola AO. 2006. Possible antidiabetic and antihyperlipidaemic effect of fermented Parkia biglobosa (Jacq) extract in alloxaninduced diabetic rats. Clinical and Experimental Pharmacology and Physiology, 33(9): 808 - 812.

Trease GE, Evans WC. 1996. Pharmacognosy $\left(14^{\text {th }}\right.$ edn). Saunders: London. 